\title{
Superior vena cava syndrome associated with longstanding implantable central venous port
}

Paulina Krzemien Santos, Ana Margarida Fernandes, Vanessa Figueiredo, Sérgio Janeiro

Centro Hospitalar Setubal, Setubal, Portugal

\section{Correspondence to} Dr Ana Margarida Fernandes, amargaridagf@gmail.com

Accepted 9 January 2015
CrossMark

\section{To cite: Santos PK,} Fernandes AM, Figueiredo $V_{\text {, }}$ et al. BMJ Case Rep Published online: [please include Day Month Year] doi:10.1136/bcr-2014-

206643

\section{DESCRIPTION}

An 81-year-old woman was diagnosed with stomach cancer 4 years earlier, and underwent haemostatic radiotherapy followed by chemotherapy, for which

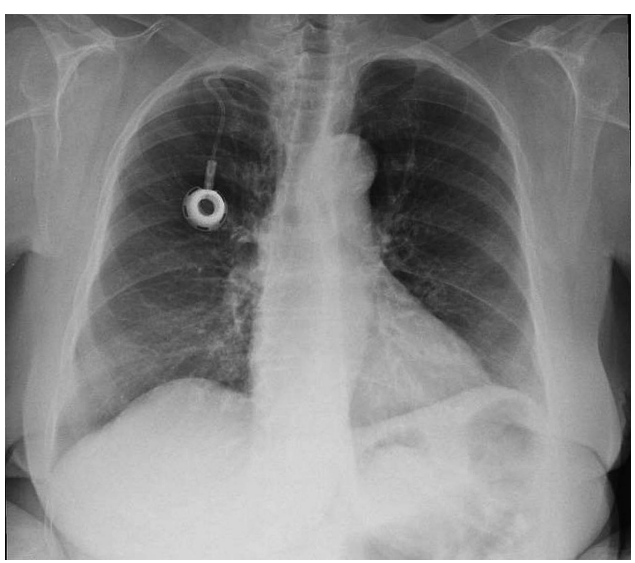

Figure 1 Chest X-ray showing longstanding implantable central venous port.

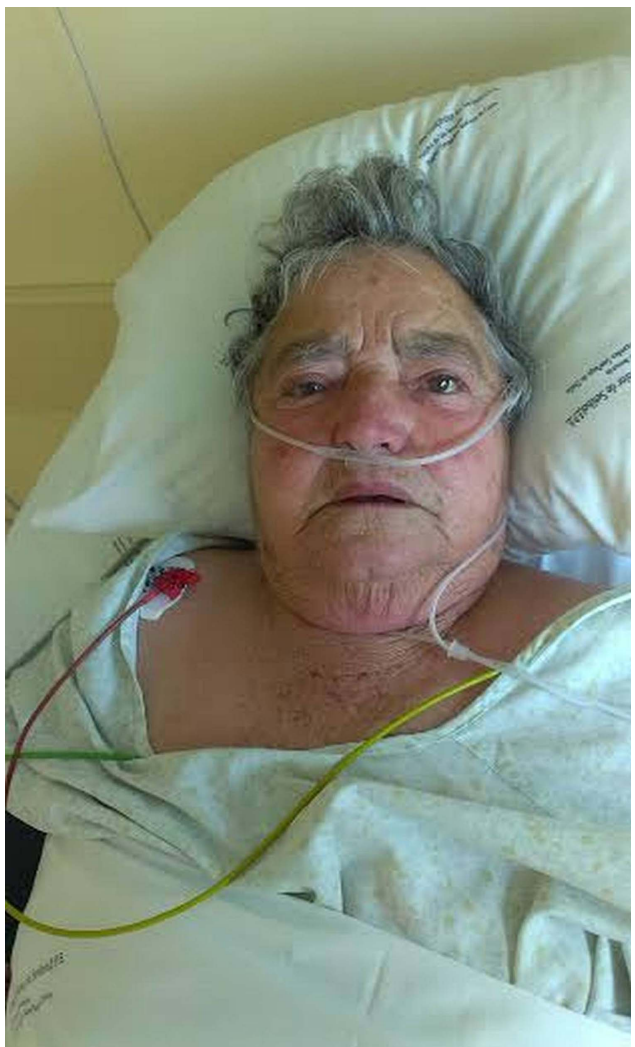

Figure 2 Photo of the patient revealing oedema and erythrocyanosis of face and upper torso. an implantable central venous port (figure 1) was placed. She subsequently underwent partial gastrectomy, with remission for nearly 3 years. She maintained regular surveillance, and presented with swelling of the neck and face accompanied by erythrocyanosis of these areas (figure 2). She also reported progressive swelling of both shoulders and upper extremities. On physical examination she was afebrile, haemodynamically stable, and had regular and rhythmic cardiac activity with facial cyanosis, and non-pitting oedema of head and neck with visible collateral circulation.

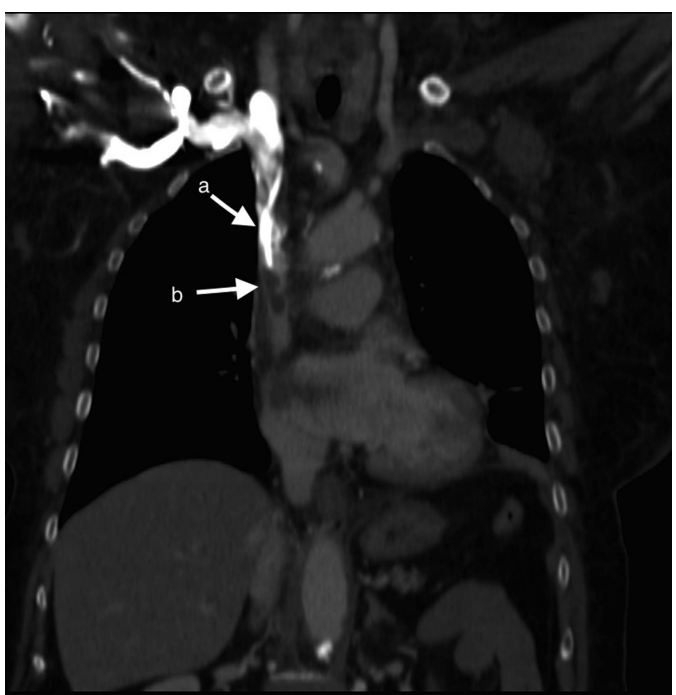

Figure 3 Chest CT scan with contrast showing (a) hyperintense image of the central venous port and (b) hypodense image of the central thrombus inside the superior vena cava.

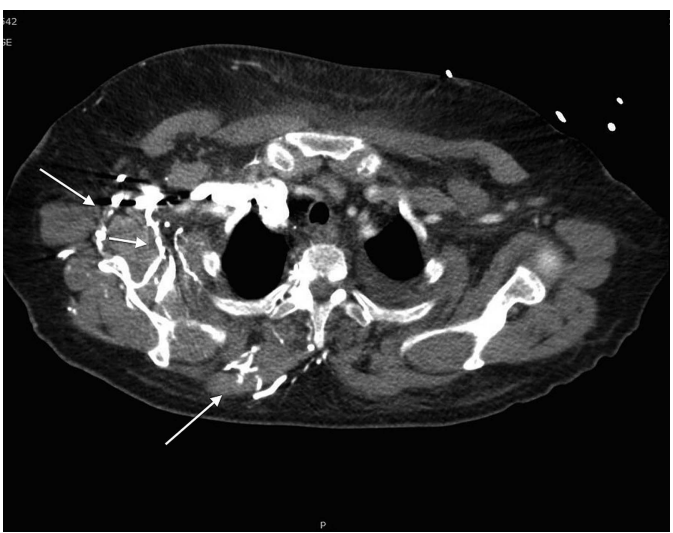

Figure 4 Chest CT scan showing extensive collateral circulation at the right chest wall and diffuse oedema of the subcutaneous tissue. 
A contrast-enhanced chest CT scan revealed intrinsic thrombosis of the superior vena cava, up to the right atrium, collateral circulation in the right chest wall and relatively diffuse oedema of the subcutaneous tissue (figures 3 and 4).

The diagnosis of superior vena cava syndrome associated with indwelling catheter was made and the patient was treated with unfractionated heparin infusion. She showed clinical improve-

\section{Learning points}

Superior vena cava (SVC) syndrome is usually suspected on the basis of medical history and physical examination, and can be confirmed by cross-sectional imaging.

- Indwelling venous catheter is a major cause of SVC thrombosis.

- Treatment should be guided by the severity of symptoms, aetiology of the obstruction, prognosis of the patient and treatment goals. ment, with regression of the oedema and facial cyanosis, and reduction of venous collateral circulation. ${ }^{1-3}$

She was referred for removal of the central venous port, and medicated with oral anticoagulation with warfarin, to be maintained for at least 6 months.

Acknowledgements The authors would like to acknowledge Dr Sónia Serra, internist at Centro Hospitalar de Setubal and Dr Daniel Batista and Dr Carlos Silva, radiologists at Centro Hospitalar de Setubal. Images gently provided by Imaging Department of Centro Hospitalar de Setubal.

Competing interests None.

Patient consent Obtained.

Provenance and peer review Not commissioned; externally peer reviewed.

\section{REFERENCES}

1 Lepper PM, Ott SR, Hoppe $H$, et al. Superior vena cava syndrome in thoracic malignancies. Respir Care 2011;56:653-66.

2 Kuter DJ. Thrombotic complications of central venous catheters in cancer patients. Oncologist 2004;9:207-16.

3 Wilson LD, Detterbeck FC, Yahalom J. Clinical practice. Superior vena cava syndrome with malignant causes. N Engl J Med 2007;356:1862-9. Review. Erratum in: N Engl J Med 2008;358:1083.

Copyright 2015 BMJ Publishing Group. All rights reserved. For permission to reuse any of this content visit http://group.bmj.com/group/rights-licensing/permissions.

BMJ Case Report Fellows may re-use this article for personal use and teaching without any further permission.

Become a Fellow of BMJ Case Reports today and you can:

- Submit as many cases as you like

- Enjoy fast sympathetic peer review and rapid publication of accepted articles

- Access all the published articles

- Re-use any of the published material for personal use and teaching without further permission

For information on Institutional Fellowships contact consortiasales@bmjgroup.com

Visit casereports.bmj.com for more articles like this and to become a Fellow 